\title{
BETWEEN THE EAST AND THE WEST: REFLECTIONS ON THE CONTEMPORARY ART OF KAZAKHSTAN
}

\author{
Madina Sultanova, Natalia Mikhailova, Dinara Amanzholova
}

\begin{abstract}
The paper analyses a self-cognitive experience performed by Kazakh contemporary art, led by globalisation tendencies, in search of its place in the world. Two decades of independence have become the basis for a new cultural space, where Kazakhstan sees itself both as the most western of Oriental countries and the most oriental of Western ones. Current lifestyles in Kazakh society, as well as the chosen political and economic vectors, considerably affect artistic consciousness, defining boundaries between ethno-cultural identity and the mainstream, which dictates its own terms and conditions.

The present study focuses on art. In our opinion, it is the most illustrative area of visual creativity, which, faster than any other, reacts to each change in social mentality. The world reflected in a picture of one artist could reflect the world of the whole nation. Now the most interesting and important questions for Kazakhstan's citizens focus on this problem. These are the same questions that can be found in the title of an emblematic painting by Paul Gauguin: Where do we come from? What are we? Where are we going?
\end{abstract}

Keywords: contemporary art, identity, Kazakhstan, search, ways

\section{INTRODUCTION}

Culture is a fate...

Lee Kuan Yew

Modern Kazakhstan is a country that continues its transformation from multiethnic to mono-ethnic. This historical fact lays at the basis of many modern social processes. After the country became independent, the Kazakhs who not so long ago represented an ethnic minority became the biggest ethnic group in Kazakhstan. In this context, many things have changed, including selfawareness and self esteem. Today these ex-nomads and ex-members of one of the Soviet republics can proudly say: "I am a Kazakh!"

The thing that was strongly eradicated in the recent past was suddenly remembered and has poured out with a huge flow on the pages of books, on city 
streets, TV screens, and Internet forums. Ethnic origin has suddenly begun to prevail over Soviet identity. Language, customs, moral and ethic orientations and mentality are only small parts of what now forms Kazakhstan's mainstream.

Is modern society ready to accept it? How is the self-determination process reflected in art? How contemporary is contemporary Kazakh art and does it really respond to the challenges of time? In this paper, we try to find answers to these questions.

Our aim is not to critique or exalt one thing at the cost of another, but to trace the nature of the deep mental processes that characterise Kazakhstan today, using the example of the evolution of artistic consciousness.

The basic analysis here is the artistic one that is directed at two stages in the development of professional Kazakh art. We talk about the art of the Soviet and independent periods: two fundamentally different artistic systems, two worldviews, transmitting the mindset of a society that was formed in less than a hundred years. We believe that art is the most truthful mirror reflecting, with no distortion, the real life of an ethnos.

\section{A CURSORY LOOK AT HISTORY}

Kazakhstan had not faced the problem of cultural identity, but then everything changed with a fundamental reverse in the history of Kazakh society in the early twentieth century that modified all the parameters of society's existence; the strongest changes concerned spiritual consciousness and the whole complex of worldview orientations.

In the 1930s the forced collectivisation of the indigenous population became a top priority on the way to inevitable industrialisation. This violated the cultural genotype of nomadism and started irreversible changes in the spiritual mentality of Kazakh society. A colossal reduction of livestock and subsequent hunger created the preconditions for the Kazakh people for an essential transition from a nomadic to a sedentary lifestyle. Radical impairing of social equilibrium, movement of tribal groups in these territories, and a negative effect on the transfer of the memory and traditions of the older generations revealed that coerced sedentarisation had become a fundamental turning point for Kazakh society and, to some extent, accelerated the inverse process of adapting to a new culture (Ogayon 2012).

By means of a rigid 'persuasion' policy, former nomads were forced to swap the freedom of the steppes for the industrial landscape of the city, and nature for the anthropogenic environment. This gave certain results: from 1926 to 1939 the republic's population increased by $2.6 \%$ and the population of cities - by 
268\%. Collectivisation, terrible per se, gave the opportunity to talk about the humanitarian crisis of the $1930 \mathrm{~s}$, when "victims of hunger were 1,798,400 ethnic Kazakhs, or 46.8\% of total Kazakh population" (Masanov et al. 2000: 376).

By the end of 1966 the number of Kazakh people was close to the level of 1926. This affected the whole population policy, making Kazakhs an ethnic minority in their original historical territory for a long time. So, as a result of active migration processes, by 1989 Slavs constituted already $44.3 \%$ of Kazakhstan's population, 7.2 million people. Due to the high level of urbanisation and education, Slavs dominated the health and social security system of Kazakhstan: $46 \%$ compared to $38.5 \%$ of Kazakhs; in science $60 \%$ Slavs compared to $25.4 \%$ of Kazakhs; in management $56.8 \%$ Slavs compared to $30.2 \%$ of Kazakhs (Zhanguttin 2009).

Physical extermination of indigenous representatives eliminated the main carriers of the gene pool, as simple nomads, keepers of tradition, and the intellectual elite, holders of the spiritual potential of the ethnic group, were under attack.

The formation of Kazakhstan's professional art school began in the 1930s and coincided with the most tragic events in the history of the Kazakhs. Perhaps the real danger of losing the internal unity of the past and present forced those who were always at the forefront of spiritual awareness - artists and poets - to find a solution. Thus, young Kazakh art manifested itself clearly and authoritatively. Visual arts, theatre, music, and films were inspired by national cultural identity, the spiritual core of which was placed in a "different context where parameters of European genres dominated; it represents a distinctive pattern of cultural symbiosis" (Sharipova 2008: 5).

Contrary to political 'excesses', the creative climate of the 1930s was extremely favourable, especially in Alma-Ata (now Almaty). You could say it was a kind of protest made by the intellectuals against terror and violence, expressed through a synthesis of traditional and new, folk and professional. Kazakh theatres annually staged several performances. The authors were Kazakhs: M. Auezov, S. Seifullin, B. Maylin, and others. The Kurmangazy State Orchestra, along with folk music, mastered the classical European repertoire, while the talented self-taught experts and collectors of Kazakh folklore - K. Zhandarbekov, A. Kashaubaev, K. Baiseitova, and many others - became the foundation of modern Kazakh theatre.

Repressions raged more severely and therefore Kazakh artists searched for ways of self-realisation more intensely. Despite the fact that there was no system of art education, their undoubted talents meant that they had the opportunity to study and work, achieving resounding success. N. Khludov, A. Ponomarev, A. Lebedev, A. Antonov, N. Krutilnikov, F. Bolkoev - these are just a few names 
of artists and artisans arrested in Kazakhstan for various (mainly political) reasons. All of them became teachers and mentors for young, talented Kazakhs, who later founded a professional art school; for example A. Kasteev, A. Ismailov, Y. Tansykbaev, and others.

It should be noted that the Kazakh intellectuals of that period always sought to unite rather than divide. Art remained a sphere that artists themselves consciously and purposefully guarded from the intrusion of politics and ideology. Even with an aggressive cultural policy, artists understood the need to preserve traditional culture.

The specificity of Kazakh professional art is mainly expressed by its content and not so much by the fact that it has started from scratch. Because of the nomadic way of life and the cultural identity of temporary art, painting as a kind of spatial art was an absolutely alien phenomenon for the Kazakhs.

Kazakhs fully possessed the required powerful spiritual charge, the core of which consisted of a pure uncomplicated traditional consciousness; all the rest was 'a trick' (Sultanova 2012: 110). For talented artists, folklore remained a reserve of high art, an actual experience. Their art was "inextricably linked with folk art, used its ideas and images, filling itself with strength and energy inherent to this type of art" (Sharipova 2008: 6).

Interestingly, it was painting that became a sort of 'testing ground' for a new, emerging artistic reality. It should be noted that in Kazakhstan painting grew vigorously between the 1930s and 1950s, in contrast to applied art, which was almost forgotten during this period. The main reason for this was the requirement of the Socialist Realism policy to create art that was "national in form and socialist in content", as was announced in the decree of the Central Committee of the Communist Party of the Soviet Union (CC CPSU), On the Restructuring of Literary and Artistic Organisations, in 1932 (Erengross 2001: 442). The fastest and the most effective implementation of this requirement was possible in painting, a brand new art form for the Kazakhs, with no internal linkage, unlike applied art which always embodied the soul of the nomads.

Adapting to new circumstances, "tradition has breathed its potential, understanding, and values in the professional art. This factor contributed to the preservation of the cultural memory of people, to the survival of traditions" (Ergalieva 2002: 5). And it really allowed the professional art school to continue its existence and to combine harmoniously a true national spirit with a new form, dictated by historical realities, but without becoming an obedient ideological tool.

The true traditional spirit, whatever form it takes, is always independent of place and time and is something constant. It is also a "purely intellectual sphere, the only one where there is no need in efforts to adapt different men- 
talities" (Guénon 2004: 189). This may be "a matter of elites only, in the fullest and truest sense of the word: we are talking about the intellectual elite only, and never there is any other, and all the social divisions do not matter" (ibid.). 'Intelligence' here is considered not as the mind or the ability to think; it is as certain shrewdness, ascended to the realm of the spirit, which is above the will. Soviet ideology, and mass repression in particular, purposefully destroyed the intellectual elite and, alongside, the Kazakh cultural matrix. The more important mission of professional art, which was made to mobilise all its forces, was to protect the most important, spiritual, core, enclosing it in a radically new visual language.

We believe that this explains the uniqueness of contemporary Kazakh art, which, having virtually no professional basis, can perceive the inner meaning of a completely alien artistic language in a short time.

\section{GUARDIANS OF ETERNITY}

Any art school in the process of formation faces the problem of finding a new physical form for the expression of 'eternal' values, i.e. traditions. Kazakhstan was no exception here.

The initial stage of the formation of professional art began in the period of the 1920s-1940s, something that Kazakh art critic Raikhan Ergalieva poetically calls a "syndrome of Antaeus" (Ergalieva 2011: 14). Like the mythical demigod Antaeus, the first Kazakh artists were not only inspired, but also nourished, by the energy of their native land.

A specific feature of the new artistic reality was the desire to preserve and transform, in a special way, traditional knowledge hidden in folklore. Folklore, "carrying a charge of emotions, ideas, originality of style, refracting in contemporary art receives double rethinking" (Ergalieva 2004: 6). This is what further defines the identity of contemporary art in Kazakhstan. It should be emphasised that this is not traditionality but rather traditions, and not just a search for an original artistic language.

Understanding the complexity of their task, the artists transformed the national awareness of colours and shapes into a special low-key colour and a certain simplicity of plot. Folk motifs became the bases of many musical and dramatic works in the scenic arts and literature, and artisans on the periphery tried to preserve their traditions in arts and crafts, while urban cooperatives and factories organised mass-production of products that were "national in form, socialist in content". 
The old image system was soon completely gone; its return could have had negative consequences, although no one could prohibit talented people from searching for their own way. They intuitively understood that they were to define the future of art. In order to find the right direction, they had to make a start, inspired by something powerful, immutable, and permanent. Representing the intellectual elite, artists turned to the spiritual ' $\mathrm{T}$ ' and tried to project oral forms developed over centuries onto canvas and paper. Just as it was before, a vivid, sparkling folklore gave content to unfamiliar forms created with the use of a new plastic language; this marked the future of Kazakh art.

Despite a strongly pronounced national identity, Kazakh art quickly found its place in the context of a long-standing world art system. This happened thanks to a folk basis, which, being original and unique, still represents a part of world traditional consciousness. In folklore, immortal spiritual values are combined with a lively sense of humour and timeless archetypes that everyone can understand.

Abylkhan Kasteev is considered the founder of Kazakh professional painting. Together with his colleagues, the Khodzhikov brothers, Aubakir Ismailov, and others, he tried to learn the secrets of an art that was new for them, in order to express images and emotions that flowed from the heart. These images were woven of variegated yarns, the colour and weaving of which were prompted by native steppes and mountains. The painters constantly felt an invisible proximity to nature, despite the fact that the city became their refuge. Their style was primitive, yet in the best sense of the word. 'Primitive' in this context should be considered as something natural, simple, and complete, lacking any superficial qualities because "primitive culture is something powerful and unified, highly viable and effective" (Spengler 1999: 43). Pointing to the work of no particular artist, we would like to find something global that lies in common between them and is a kind of national idea which became the dominant concept in search of identity.

In the work of artists of the 1920s-1940s, traditional cultural content animates everything, showing that a new reality can be created not from the ruins of the old one, but on its foundation. Masters did not directly follow folk stories, but, nevertheless, the poetics of their native land, its eternity and its people were the main themes of their artistic searches. Only the language had changed.

Portraits, landscapes, genre paintings, etc., are not just 'covered' with folk motifs, but are immersed in them. It is impossible to separate or remove these motifs because in their artless simplicity and truth they represent life itself. The steppes and the mountains, the pungent aromas of dry plants and animals are not just a background for people, but are the main protagonists, the true heroes without whom the world is impossible. 
In pursuit of 'national originality', artists did not resort to purely superficial evidence of their ethnic origin. They embodied the infinite involvement in traditions of the native land that generously fed their talent. Heidegger supposed that art as a process of creating within the creation of truth is poetry. Creation is real only when we detach ourselves from our everyday lives, intruding into an open creation; and then in this way we affirm the truth of our being in the truth of being (Heidegger 2008: 209). This perfectly captures the essence of the philosophy of Kasteev and his followers, which argues that if art is poetry, then folk poetry becomes visible visual art thanks to the talent of the artist.

It can be explained by the special status of poetry and word art among Kazakh nomads. In the culture of the nomads, verbal types crown the improvised pyramid of the arts. Artists managed to express all the wealth and variety of the poetic gift of nomads through special colour sensation, forming a picture of the world.

A striking example are the paintings by Abylkhan Kasteev, Kolkhoz Dairy Farm (1936), Milking the Mares (1936), Portrait of a Young Abai (1945), Anarkhan (1953), Khan-Tengri (1959), and Cours Torgai (1955), and Aubakir Ismailov's Nomadic (1931), and Crimson Autumn (1931), as well as the works of Ural Tansykbaev, and many other works of art of the period.

The main trend in the Kazakh art of the 1950s could be called 'Land of Grandfathers'. This constitutes the stage of maturity of the national art school (Ergalieva 2011: 56). Moldakhmet Kenbaev, Sabur Mambeev, Kanafia Telzhanov, Sakhi Romanov, and others were a new generation raised by the socialist system. They received a professional education at leading universities in Moscow and Leningrad (now St. Petersburg). Their perception of the world was different, as "Kazakh school of painting, developing in line with Soviet art space, was isolated from the world processes" (Baturina 2009: 64). Social realism as a truly imperial style influenced everything and especially ideological content. It was possible to create only in the 'right' way. But Kazakhstan with its simplicity and ingenuousness did not go very well with the bright, glossy, pretentious decorations of ideologically restrained formal orientation.

The open spaces of the boundless monochrome steppe and extra temporality of the Kazakh relief disposed artists to reflections and to the aspiration to learn about themselves. This was discordant with beauty and the pathetics of collective-farm life where everything was, at least to some extent, always in the public eye.

This acute conflict of form and content forced young artists who had grown up in industrial landscapes to look for inspiration and creative energy in the eternity of nature. Former mental orientations, clearly defined by the first generation of artists, were transformed into epic-romantic poetics. It is impor- 
tant that professional art educations obtained in the best academies caused an incredible enrichment of figurative language. Access to the fine art schools of the world let Kazakh artists actively experiment with composition and colour.

Almost all paintings of that period are characterised by bright individuality. Each artist had his own style, but together they all followed the same semantic code, which we would call 'consent'. This term can be considered a fundamental unity of the categories inherent to the philosophy of the life of the nomads: harmony with nature and freedom of spirit. M. Kenbayev's pictures Conversation (1958) and Catching of a Horse (1961), K. Telzhanov's canvases On the Earth of the Grandfathers (1958) and Page Mambeev at a Yurta (1958), and many others, are indicative here.

Although for the entire Soviet space this period was marked by political 'thaw', a dissonance between the external and the internal, between the shell and the meaning, continued to deepen. Therefore, it was necessary for Kazakh art to find the delicate balance that would bring together an individual and the world around him. Thanks to this strong and intense energy of national expression, the art of the 1950s became, and remains, the first important period of artistic expression for Kazakh identity.

We should note another key aspect that would be inherited by subsequent decades - improvisation. For the Kazakh worldview, the ability to improvise is the basic ability. This is the core of traditional consciousness transmitted by means of folklore. Developing predominantly not spatial, but temporal arts, the nomads of the Great Steppe honed verbal forms of communication with the world. The greater was the pressure from the outside, the more the creative spirit opposed; with improvisation this went deeper into the ethnic basis.

The 1960s were the period of Kazakh art's 'self-identification'. In contrast to the soft, subtle and heartfelt lyrics of the 1950s, this stage formulated its credo dramatically and fundamentally as a search for a national style. The language of this style should be simple where possible, solid and clear as ancient symbols that have the same meaning in all world cultures.

We can say that in that period Kazakh artists wondered just like Paul Gauguin, who a few decades earlier had left the Old World for a forgotten 'innocence' of soul and heart. Bright, symbolically rich decorative brushwork became a kind of 'message' of civilization. The artists of the Blue Rose creative association sought the truth just like Gauguin, although not in exotic Pacific islands, but in the Kazakh steppes, where little had changed for hundreds of years. 'Eternal nomadism' is imprinted in the paintings of Pavel Kuznetsov as a lost idyllic paradise.

Salikhitdin Aitbayev, Tokbulat Togusbaev, Shaymardan Sariev, Oralbek Nurzhumaev, Abdrashit Sydykhanov, and others inherited a complex range 
of traditions, as well as problems of continuity, identity, and political ideology; they were ready to rethink the entire mainstream art system. Constantly improving their technique and intelligence, relying, as we could say, on world artistic heritage, the artists of the 1960s were looking at themselves not just as painters, but also as a link in the chain of generations. In this context, their priority was the aspiration for self-identification and mental separation from cultural unification, for spiritual independence and a search for inner freedom.

They were looking for a way through figurativeness, symbols, metaphors, and allegories of classical oriental art. They were fascinated by the expressiveness and conciseness of traditional Japanese art. They were inspired by the inclination to minimalism, embodied in the special aesthetic categories of "wabi - the beauty of poverty, severe simplicity, roughness, and sophistication at the same time, and yugen - the inexpressible by means of language truth" (Kanevskaia 1990: 11). The Muslim miniature was also attractive in its perfected technique of "translating life images into the language of art" (Ergalieva 2011: 114).

Awareness of the value of traditional culture and a vast artistic experience of synthesis led to the birth of a so-called 'severe style', which characterises the Kazakh art of the 1960s. The artists of this decade drew bold parallels between the aesthetics of ancient nomads and the artistic language of Matisse, Gauguin, Van Gogh, and Cezanne. They were not just experimenting, they were looking for meaning. Thus, they were gradually getting rid of unnecessary shells, and developing a proper, deeply original, Kazakh national style. Crisp and clear, it is distinguished by deliberately simplified forms, even by a certain severity, or, in other words, maturity.

In support of this, we can cite the example of the paintings Women of My Homeland (1967) by Ali Dzhusupov, Young Kazakhs (1967) by Salihitdin Aitbayev, Under the Sky of the Motherland (1970) and Shepherd (1969) by Sakhi Romanov, Kitchen (1972) and Birth Song (1970) by Shaymardan Sarieva, and more.

A canvas by S. Aitbayev, called Happiness (1966), can be considered the most significant here as it makes us remember traditional Kazakh felts with their static nature. The images of a young shepherd and his wife are as if they were imprinted, woven into the narrative fabric, and their angularity does not render the composition heavy. On the contrary, they are full of confidence and clarity. The viewer immediately identifies the noble traits of each of the characters, despite the lack of grace and sweetness. Thus, we immediately recognise, in an ancient bronze Saka badge coated with the patina of time, an authentic masterpiece that has nothing in common with the trendy glitter of jewellery alloys. 
Here the pictorial space is intentionally simplified to the extreme, refined of all that is strange or unnecessary; the only thing that remains is the foundation on which ornaments of the newlyweds' happy present and future are 'hammered'. The restrained colours echo the compositional structure of the work, and simple, clear tones, natural and expressive, organically supplement the whole picture. With this canvas, Aitbayev sought to create a fundamental image of the native homeland, eternal in its wisdom as the vault of heaven over the vast steppe.

Adepts of the 'severe style' clearly formulated what their precursors were searching for by intuition. The artists of the 1960s created a true national style that combined the solidity of the former artistic language with the dynamics of the current one.

The next stage in the development of Kazakh art is conventionally said to be the 1975-1991 period. It is marked by an active artistic search without any homogeneous cohesive nature, as was the case in the 1960s. A new generation of artists finally adapted to the international art space and constituted a distinctive professional school. It should be noted that knowledge and skills were implemented much more freely. Artists experimented boldly, incorporated new techniques, searched persistently for themselves and their own styles.

The ideological situation of that time created an inertia of utopian ideas, which were increasingly debunked. In political history this period is called 'the years of stagnation', although this aspect does not concern art. A distinctive feature of this stage was latent searches. This can be explained by the fact that under the influence of external factors old heroic pathos was fragmented and heterogeneity of artistic searches took over for each artist. The decisive factor here was the discrepancy between the desired and the actual.

A hero who overcomes time and space is a central theme in the art of that time. This concept is the exact opposite of the traditional worldview and is released by hyperbolic artistic methods. The works of those years are deliberately ambitious and impressive. They feature plenty of air and light and in the foreground there is often matter, altered by human hands and consciousness.

An exaggerated exaltation of man's status that had nothing in common with his real state led to a greater individualism that excluded recourse to spiritual basis and, as a consequence, to dark painful reflections, anticipation, and excitement, which was characteristic of the emotional world of fine art of the late 1970s and early 1980s.

It is in the crucible of doubt and disappointment that around the end of the 1970s and beginning of the 1980s a new artistic vision began to crystallise, seeking to reconcile the needs of real time and traditional cultural constants. In order to find the lost space, artists did not withdraw into themselves, but 
actively looked for common ground with everything that was new. The artists of the 1970s were nourished by the environment of companionship of philosophers, poets, writers, artists, and architects. As per the period, all this was often of an informal nature (Iusupova 2009: 8).

'People of the seventies' discussed the Moscow and Leningrad (today St. Petersburg) exhibitions with great feeling, greedily listening to those who managed to visit (sources of information other than official were difficult to get). Practically all the 'people of the seventies' were well educated, and distinguished by their liberal views from other artists of the era. Their world was formed by national traditions and creativity of postimpressionists, music of The Beatles, Kierkegaard, and Camus's philosophy.

Unlike the 'people of the sixties', who followed, to a greater or lesser degree, the uniform method of socialist realism, since the 1970s there has been an era of 'loner heroes', and as part of this identity has realised itself, winning against the instinct, and the slogan, of solidarity of purpose (Malinovskaia 2004: 25). S. Aytbayev, S. Sariyev, and M. Kisamidinov, the brightest and most tragic figures of those years, were constantly in the thick of things, while at the same time feeling like 'stepsons of the era'. However, the art they created was about building bridges between different schools, instead of destroying or subverting as it used to be in the nineties.

After the success of yesterday's 'renegade' works in the international cultural community, non-conformist art acquired a long-awaited freedom, which allowed artists to expand their creative search. Suffocation in the grip of ideological consciousness began and eagerly absorbed everything. Thus "in the late 1970s and in the 1980s, art briskly outgrew all possible '-isms', gaining the desired experience and the necessary immunity" (Ergalieva 2002: 68).

Kazakh professional art required almost sixty years to become independent and able to determine its own destiny. The creative community in its search for direction referred to the entire world's cultural and artistic heritage - to the figurative monumentality of Italian Trecento, the oriental miniature, French Post-Impressionism, and Russian avant-garde. Such diversity was dictated by the need to find an intuitive sign of spiritual unity as support for the development of a proper original artistic vision.

For several reasons Kazakh art had to be equal to Soviet art, which, from 1934, in turn headed for ideologically restrained Russian Itinerants (V. Perov, I. Repin, V. Surikov, I. Kramskoi, and others) (Nakov 1991: 135). This fact always pushed progressive artists to seek actively for a national identity, which is particularly characteristic of the stagnant years of the 1970s and 1980s. By the 1990s, a special artistic energy potential had been formed, which was based on the professional school, which outgrew serious and superficial passions 
for different, spiritually alien elements from the Western social and cultural environment.

In Alma-Ata in the 1980s, despite a ban, students' exhibitions by the groups Green Triangle, Night Tram, Red Tractor, Intersection, and others, from Karaganda, Guryev (now Aktau), and some other large cities, promoted art more actively. Being, in fact, nonconformists, many gifted artists experienced hard times because of their protests against Soviet cultural policy. Diplomas from art schools and other institutions were withheld from some (K. Dzhapargaliyev, E. Tarasevich, V. Lebedev), while some were tragically lost young, having committed suicide or succumbed to madness (K. Dzhapargaliyev, S. Vorobyova, B. Koroteyev, A. Kim).

For Kazakhstan, the 1990s became a time of transformation of thought and a fundamental reorganisation of national consciousness and national psychology. As E. Malinovskaia writes, "art practice in the 1990s fixed in national consciousness the socio-cultural function of modern art, breaking the stereotype of Soviet ideology about the proximity and clarity of art to the people" (Malinovskaia 2000: 71).

Therefore, it becomes obvious that at each of the stages of the development of Soviet art in Kazakhstan ethnic origin was not lost but carefully guarded, being transformed into a new figurative shape. The harder was the ideological pressure, the more artists opposed this reality. We are talking here about real art reflecting fates of real people, crippled by the system, rather than 'court' officialdom.

\section{THE TWENTY-FIRST CENTURY: IN SEARCH OF 'HOME'}

When Kazakhstan gained its sovereignty, the process of a large-scale development of the national idea strengthened. It was not just the formation of a domestic art system at a new point on the political map; it was the formation of a 'national model of the world', which could be implemented only through culture and art.

In Asia, Kazakhstan, ahead of other ex-Soviet republics, a new reality began to form and, fortunately, it has avoided civil strife and armed conflicts, even if its independence was not so easy to win. Now for Kazakhstan, as for no other country in the post-Soviet space, the problem of self-determination became important. This can be explained in terms of its special geographical position and the resulting cultural paradigm. It seems to be clear: over three thousand years the local society was nomadic, but from the twentieth century it became sedentary, with a rich and distinctive culture. However, it is difficult for modern 
Kazakhstan citizens to position themselves unambiguously, as from the political and social point of view we are 'the most Western of the Eastern countries', while in mentality - 'the most Eastern of Western countries'.

Here we mean an interesting and sometimes paradoxical combination of two different planes: a 'Western' concept of life and its purely 'Oriental' rethinking, characteristic of modern Kazakh youth. Recently, raucous rock music coming from an old transistor radio attached to a herder's saddle in a steppe that was deserted for two or three hundred miles seemed quite a common phenomenon for Kazakh society. But a youth flash mob action called Kara-Zhorgha ${ }^{1}$, held on May 13, 2011, in one of the largest shopping malls in Almaty, generated a strong reaction on the Internet. Opinions were split, ranging from obviously enthusiastic (expressed mainly by young people) to downright negative (expressed mainly by people from the middle and older generations). The essence of the claims was that young people lacked understanding of the history and meaning of the dance in question (although the majority of middle-aged people are also not so knowledgeable about traditions).

However, according to the participants in the flash mob, apart from the opportunity to participate in such an event, there was also a sincere desire just to perform this dance, and in this way popularise national culture; eventually the online community was obliged to investigate dozens of Internet sites looking for information about the Kara-Zhorgha dance, to listen to ethnic music and different artists in this genre. Moreover, the discussion on Internet forums went beyond Kazakhstan, involving young people from other countries. In any case, the action was very important and produced convincing results: nothing else would make young people spend their precious time finding something that interested them.

This event shows different sides of the process of globalisation for Kazakhstan: on the one hand free and broad access to information and education, possibly with a wide choice - where and how to live, study, work. On the other hand there are minuses, "particular fear is caused by the loss of national sovereignty when the status of the independent state is formally preserved" (Shalabayeva 2007: 157). It is clear that globalisation is an inevitable and justifiable phenomenon in terms of mankind's evolution. Moreover, it is the only sound course in the context of sustainable development, which cannot be performed independently by a single country, separately from the rest of the world. It is also clear that a strategy that is adequate for a particular type of society does not make sense for other countries. Thus, the main thing to consider here is cultural identity.

Today, Kazakhstan as a full-fledged participant in world affairs is rapidly integrating into the global community; this involves not so much the economic, 
but peoples' cultural potential. Here we face the fact that today's Kazakhstan is a strongly multiethnic state where the titular ethnic group predominates. Because of this fact, the problem of cultural identity becomes complicated to some extent as it comes into contact with other subject areas, for example religion, politics, etc. We think that for Kazakhstan the Singaporean experience, the key priorities of which are culture and family, is extremely valuable (Fareed 1994). These two concepts are inseparable from each other, because one presupposes the other. Unfortunately, in modern Kazakhstan there are problems with both aspects of this.

Kazakh people came to be in a difficult and controversial situation because for seventy years the society was trying to create a special type of a citizen, satirically called 'homo sovieticus' (Zinoviev 1991). At least two generations were raised with a full sense of this. In the field of art this was felt particularly acutely. Strict censorship, absolute obedience to political ideology and cultural unification stopped any attempt to deviate from the 'correct' course. Those who in some way stood out against this background were immediately noticed. A public response appeared, which was generally negative.

Independence has changed everything and has also highlighted another problem. Now, when everything is possible, any artist whose path to official academic education is forbidden for some reason (or he/she just has no aspiration for it), may exhibit his/her work in an alternative gallery or publish them on the Internet, where there is always an audience. This means that whereas earlier there was a lonely voice, sounding in the silence, now the individual cannot be heard in the general hubbub.

Considering this background, some contemporary artists (especially those from the late 1990s and turn of the 21st century), tried to stand out from the crowd by relying solely on originality. They understood the concept of the return to basics (Malinovskaia 2000: 72) rather superficially and exploited 'national identity', transforming it into a brand that only alienates us from the true home. Sometimes impeccably drawn horses, wolves ${ }^{2}$, and batyrs ${ }^{3}$ represent only a shell, a shape with no inner sense and content. If we talk about negative aspects of this phenomenon, we can identify weak and sometimes completely absent knowledge of the basis of traditional folklore, liberties with historical facts and established visual forms, such as ornaments. All this, being a manifestation of culture, originates in the institution of family, meant to keep and transmit knowledge and respect for it by inheritance.

We observe certain 'distortions' in the Kazakhstan art of the last two decades. Fortunately, this is not normal, but there is no sense in hiding the obvious. We are not going to criticise anyone in particular. However, considering artistic creativity as one of the most delicate and sensitive areas of human spirit, we 
can draw the logical conclusion that contemporary artists are desperately and sometimes literally blindly looking for a way to themselves. But in general, this indicates that the problem concerns the whole nation.

If we continue to reflect on the methods and investigations of independent Kazakhstan's art, it becomes obvious that despite difficulties of a different kind, the 'artistic genius' of Kazakh people has found new possibilities of self-expression. Already by developing habitual forms like painting, graphics, etc., art organically expands its space through innovative forms, for example installations environments and artistic events that go far beyond the 'figurative'. Khalima Truspekova calls these phenomena 'tectonic shifts' (Truspekova 2011: 266).

It should be noted that in the last few years the main trends in Kazakh art have changed. Close attention has been given to the 'old school', which was able to see and not just to look. Today, artists have unlimited opportunities to learn professional skills; there are new materials and technologies at their service (graphics tablets, software, etc.). The desire to identify oneself as part of an ethnic group emerges more and more clearly: apart from subject preferences, this is easily visible in the works. An invisible national character is clearly revealed through this borrowed artistic manner. We see here the consonance of form and content as a harmonisation of professional and spiritual maturity of contemporary Kazakh art.

Recently the interest in ancient archaic cultural layers has increased. An appeal to signs, symbols, petroglyphs, Turkic runes, and tamga ${ }^{4}$ evidences the searches for some initial code as a universal language. At that time the steppe and nomads did not know the strict territorial boundaries and ethnic differentiation that exist now. Society was brought closer together by a common way of life and, therefore, of thinking. We argue that for modern art this is the most important aspect. Artists, despite the media they specialise in (painting or applied art), are trying to construct their own space on the basis of universal symbolism.

In our opinion, one of the brightest and most significant events in the context of this research is a creative contest organised by A. Kasteev, called The Kazakh National Epos: The History and Traditions of the Kazakh People, which was held on December 12, 2012, at the State Art Museum of the Republic of Kazakhstan (SAMRK). The initiators and organisers of the contest were the SAMRK and a non-state company called ArLine. This full-scale cultural project was devoted to the Independence Day of the Republic of Kazakhstan and was aimed at "the creation of paintings of high artistic standard, significant by content and level of workmanship". ${ }^{5}$ Only those artists, who had completed higher or specialised secondary art education, were taken into consideration. 
Those chosen represented a solely realistic manner of painting, and painted on large format canvases in oils.

The goal of the contest was not only to promote national art, but also to make an attempt to see the true trends in contemporary Kazakh artistic consciousness. Very strict conditions imposed by the organisers had clearly drawn priorities: the combination of the Western academic school and an Oriental awareness of the history and meaning of what is happening now. It is no coincidence that this was a reference not just to history, but to the epos as one of the brightest manifestations of folklore. Epos, customs, and traditions act here as the most important parameters of Kazakh culture, transmitted through family and home.

Three winners - Dosbol Kasymov, Kazakbay Azhibekuly, and Esengali Sadyrbaev - were selected from among 107 participants. We want to note that in the absence of age restrictions, the prize-winners all came from the same generation, 'generation X', born in the 1960s.

According to the demographic theory of N. Houva and W. Strauss, the socalled 'generation X' or a generation of 'wanderers' (nomads) emerges during the time of changes which give birth to new social ideals and spiritual priorities. Such a new generation passionately attacks the established institutional order, and is therefore often remembered later as the group very focused on achieving their goal in a period of turmoil (Isaeva 2011: 292).

Here we mean that the youth and creative formation of these artists fell into the 1980s and 1990s - the so-called period of stagnation and the radical changes subsequent to it. The 'wanderers-nomads' are a force, capable of resisting the power structures of the state and society (ibid.: 294). These painters originate from the 'old' (professional) school, featuring a steady picture of the world, and ability to see the essence of traditional folklore as an important element of cultural memory.

On the whole, the work of many of the young artists demonstrates only superficial ideas of traditional culture, folklore, and national history, which indicates weakening of their ethnic memory.

For now this contest is the first and only one, but even this limited experience is extremely valuable. Kazakhstan has a very strong school of sign painting, which emerged in the late 1990s. This figurative language has helped in many ways to make the so-called transition from unification to identification and creation of a new art coordinate system. As earlier nomads marked their living spaces with tamgas, symbols, and ornaments, so in the era of independence we have resorted to the same approach. However, the above-mentioned project was aimed at overcoming the eternal East-West dichotomy by means of visual figurativeness and a core semantic combination. 


\section{CONCLUSIONS}

It is certainly early to talk about the contemporary art of Kazakhstan as about a complete phenomenon: there has been too little time to go through and understand everything without losing the connection between generations. Now professional art is extremely saturated with global ideas that are sometimes difficult to understand. One of these ideas is that of freedom, which passes like a red line through the whole artistic consciousness of modern Kazakhstan, whether we talk about social or artistic freedom.

Endlessly experimenting, artists string lost fragments of ethnic memory on the thread of life, creating not just a new pictorial language, but also a national picture of the world. A familiarisation with proper history, Turkic and Tengrian cultural traditions and the aesthetic categories of the East in all their diversity fully capture the generation that has entered the art of an already sovereign country. Here we can observe the desire to turn Kazakh art back to its harmonious 'Oriental' direction.

Perhaps this can be explained by the absence of a main stylistic trend. At the moment, "there are two directions to find the identity: a visible extraverted manifestation of the national idea and its inner introverted transformation" (Ergalieva \& Truspekova 2009: 53). Accordingly, there are realistic and historicalethnographic layers. The main link here is the artist him- or herself, because it is through them that the contact between present and past is implemented.

Therefore, we can conclude that in contemporary Kazakh art, and in painting especially (as the most demonstrative field), the old mechanisms of perception and national consciousness are still active and function in a discreet but extremely effective way. Being transformed into the core of ethnic worldview, they are responsible for national identity in contemporary culture.

Summarising our short study, we have found that within two decades of independence modern Kazakh society, not without difficulty, has managed to find an equilibrium that constitutes the Kazakh mentality and keeps a balance between East and West. The result of this is the fact that the people of Kazakhstan equally perceive themselves as 'Kazakhs' and as 'citizens of Kazakhstan'. Here a 'citizen of Kazakhstan' is not Soviet heritage. We think that, on the contrary, the Kazakh citizen can be considered a full-fledged element of a unique new society, which is not divided in two different orientations but can balance and unite both.

Art, like no other part of human consciousness, is able to express these processes occurring latently or violently forcing their way out. In a short time, contemporary Kazakh art has managed not only to acquire professionalism, but also to establish its own schools that perfectly fit in with the global cultural space. At each stage of its development Kazakh art has intuitively found 
its speciality: the most objective figurative language. This manifests itself as mental codes that cannot be seen but are unmistakably felt as specific visual forms peculiar to different historical epochs.

Now, despite all distortions and excesses stemming from the abuse of 'national originality', the contemporary art of sovereign Kazakhstan continues to evolve, based on the synthesis of old school achievements and the awareness of self-identity.

\section{NOTES}

1 Kara-Zhorgha ('black pacer') is an ancient traditional Kazakh dance performed mainly by men, as it probably had a ritual shamanistic nature. In addition, it is believed that this dance was meant to be performed by young men and women, symbolising the harmony of the two principles (Abirov \& Ismailov 1984).

2 The wolf is an ancient Turkic totem known in proto-Turkic culture from the Bronze Age. The first images originate in numerous petroglyphs from Central Kazakhstan (Margulan 2003: 14). The wolf or she-wolf is the main character of genealogical legends of many Turkic peoples, including Kazakhs. In this context, the image of the wolf is the identification of Kazakhs, the embodiment of their best mental and physical characteristics: courage, strength, endurance, the ability to be a part of the pack without losing individuality, etc. (Kondybai 2005: 97-100).

3 Batyr (from Turkic 'Bahadur') in Kazakh culture is a warrior, a brave defender of people, who has not only physical strength, but also a broad mind, compassion, and desire for justice.

4 Tamga is a generic family sign. The etymology of the word dates back to the early Turkic era, although tamgas themselves have been known in the Asian steppes since the Bronze Age. Tamga is a simple geometric symbol based on a circle, a vertical, a square, a rhombus, etc. When a new branch was separated from the main clan, it enshrined the right to its own tamga, which, however, was always a derivative of the initial symbol. Often tamga encrypted general ideas about specific properties of the tribe; for example, the tamga of the Kazakh clan Aday, belonging to a small horde (Juz) in western Kazakhstan, represents a stylised image of the arrow. The Aday clan was famous for their military valour, indomitableness, and the best archers (Castagné 1906: 180).

5 See http://www.gmirk.kz, last accessed on January 26, 2016.

\section{REFERENCES}

Abirov, Dauren \& Ismailov, Aubakir 1984. Kazakhskie narodnye tantsy. [Kazakh Folk Dances.] Alma-Ata: Oner.

Baturina, Olga 2009. Peizazhnaia zhivopis' Kazakhstana. [Landscape Painting in Kazakhstan.] Almaty: Areket. 
Castagné 1906 = Kastan'e, Zhozef. Otchet o poezdke v Turkestan. [Report on the Visit to Turkestan.] Trudy Orenburgskoi Uchenoi Arkhivnoi Komissii: Vypusk XVI. [Works of Orenburg Scientific Archive Commission: Issue XVI.] Orenburg: Parovaia Tipo-litografiia F.G. Karimova, pp. 176-200. Available at https://docs. google.com/file/d/0B0K47JLp4QpaQ1FxWUJCckZ0V1U/edit, last accessed on January 26, 2016.

Erengross, Bella 2001. Mirovaia khudozhestvennaia kul'tura. [World Artistic Culture.] Moskva: Vysshaia shkola.

Ergalieva, Raikhan 2002. Etnokul'turnye traditsii v sovremennom iskusstve Kazakhstana: Zhivopis'. Skul'ptura. [Ethno-Cultural Traditions in Contemporary Art of Kazakhstan: Painting. Sculpture.] Almaty: Gylym.

Ergalieva, Raikhan 2004. Ot poezii skazanii k poetike krasok: Fol'klornye obrazy i motivy $v$ kazakhskoi zhivopisi i grafike. [From the Poetry of Legends to the Poetics of Colours: Folkloric Images and Motifs in Kazakh Painting and Drawing.] Almaty: ILI MON RK.

Ergalieva, Raikhan 2011. Etnicheskoe i epicheskoe v iskusstve Kazakhstana. [Ethnic and Epic in the Art of Kazakhstan.] Almaty: Zhibek Zholy.

Ergalieva, Raikhan \& Truspekova, Khalima 2009. Izobrazitel'noe iskusstvo Kazakhstana: Period nezavisimosti. [Visual Arts of Kazakhstan: The Period of Independence.] Almaty: Arda.

Fareed, Zakaria 1994. Culture is Destiny: A Conversation with Lee Kuan Yew. Foreign Affairs, Vol. 73, No. 2, pp. 109-126. Available at https://paulbacon.files.wordpress. com/2010/04/zakaria_lee.pdf, last accessed on January 26, 2016.

Guénon 2004 = Genon, Rene. Krizis sovremennogo mira: Izbrannye proizvedeniia. Traditsionnye formy $i$ kosmicheskie tsikly. [Crisis of the Modern World: Selected Works. Traditional Forms of Cosmic Cycles.] Moskva: Belovod'e. Available at http://lib.ru/POLITOLOG/genon.txt_with-big-pictures.html, last accessed on January 26, 2016.

Heidegger 2008 = Khaidegger, Martin. Istok khudozhestvennogo tvoreniia. [The Source of Artistic Creation.] Moskva: Akademicheskii proekt.

Isaeva, Marina 2011. Pokoleniia krizisa i pod"ema v teorii V. Shtrausa i N. Khouva. [Crisis and Rise Generations in W. Strauss and N. Howe's Theory.] Znanie. Ponimanie. Umenie, Vol. 3, pp. 290-295. Available at http://cyberleninka.ru/ article/n/pokoleniya-krizisa-i-podema-v-teorii-v-shtrausa-i-n-houva, last accessed on January 26, 2016.

Iusupova, Ardak 2009. Zhivopis' Kazakhstana 1980-1990-kh gg.: puti i poiski. [Kazakhstan Painting of the 1980s-1990s: Ways and Searches.] Astana: Foliant.

Kanevskaia, Natalia 1990. Iskusstvo Iaponii. [Japanese Art.] Moskva: Gosudarstvennyi muzei iskusstva narodov Vostoka \& VRIB "Soiuzreklamkul'tura".

Kondybai, Serikbol 2005. Kazakhskaia mifologiia. [Kazakh Mythology.] Almaty: Nurly Alem.

Malinovskaia, Elizaveta 2000. Khronika khudozhestvennoi zhizni Kazakhstana nachala 90-kh gg. [The Chronicle of Art Life of Kazakhstan at the Beginning of the 90s.] In: E. Malinovskaia (ed.) Aktual'no ob aktual'nom: Sbornik statei o sovremennom iskusstve. [Topically about the Topical: Collection of Articles about Modern Art.] Almaty: AIK, pp. 65-77. 
Malinovskaia, Elizaveta 2004. Romanticheskaia bitva bez pobeditelei. [Romantic Fight without Winners.] In: E. Malinovskaia \& V. Titen (eds.) Antologiia iskusstva Kazakhstana. T. 1. Zhivopis. Kollektivnaia monografiia. [Anthology of Art of Kazakhstan. Vol. 1. Painting. Collective Monograph.] Almaty: Tau Kainar, pp. 24-27.

Margulan, Alkey 2003. Sochineniia, T. 3-4. Petroglify Saryarki: Graviury s izobrazheniem volch'ego totema. Kamennye izvaianiia Ulytau. [Collected Works, Vol. 3-4. Saryarka Petroglyphs: Engravings Depicting the Wolf Totem.] Almaty: DikePress. Available at http://library.psu.kz/fulltext/buuk/a71.pdf, last accessed on January 27, 2016.

Masanov, Nurbolat \& Abylozhin, Zhulduzbek \& Erofeeva, Irina \& Alekseenko, Alexander \& Baratova Galina 2000. Istoriia Kazakhstana: narody i kul'tury / Ucheb. posobie. [History of Kazakhstan: People and Culture. Textbook.] Almaty: Dike-Press.

Nakov, Andrei 1991. Russkii avangard. [Russian Avant-Garde.] Moskva: Iskusstvo.

Ogayon 2012 = Ogaion, Izabel. Massovaia sedentarizatsiia kazakhov kak rezul'tat goloda 1929-1932-kh gg. [Mass Sedentarisation of Kazakhs as a Result of Hunger of 1929-1932.] Materialy mezhdunarodnoi konferentsii "Golod v Kazakhstane: tragediia naroda $i$ uroki istorii." [Materials of the international scientific conference "Hunger in Kazakhstan: Tragedy of the People and History Lessons.] June 1, 2012, Astana. Available at http://e-history.kz/ru/contents/view/1450, last accessed on January 27, 2016.

Shalabayeva, Gulmira 2007. Kazakhstan: ot drevnikh tsivilizatsii k sovremennosti. [Kazakhstan: From Ancient Civilizations to the Present Day.] Almaty: Ekonomika.

Sharipova, Diliara 2008. Ocherki kazakhskogo izobrazitel'nogo iskusstva: Period stanovleniia (1930-50-e gody). [Sketches on Kazakh Art: The Period of Formation (1930s50s).] Almaty: Arda.

Spengler 1999 = Shpengler, Osval'd. Zakat Evropy. T. 2: Vsemirno-istoricheskie perspektivy / Per. s nem. S. Borich. [The Decline of the West. Vol. 2: Global Historical Perspectives.] Minsk: Popourri.

Sultanova, Madina 2012. Fenomen 'chistogo iskusstva'v khudozhestvennykh traditsiiakh kocheunikov. [The Phenomenon of 'Pure Art' in the Artistic Traditions of Nomads.] Germany: Lambert Academic Publishing.

Truspekova, Khalima 2011. Avangardnye idei XX veka v zhivopisi i aktual'nom iskusstve Kazakhstana. [The Avant-Garde Ideas of the 20th Century in Painting and Contemporary Art of Kazakhstan.] Almaty: CREDOS.

Zinoviev, Aleksandr 1991. Gomo sovetikus: Moi dom - moia chuzhbina. [Homo Sovieticus: My Home - My Foreign Land.] Moskva: Korinf. Available at http://royallib. com/book/zinovev_aleksandr/moy_dom__moya_chugbina.html, last accessed on January 26, 2016.

Zhanguttin, Baurzhan 2009. Migratsionnaia politika Kazakhstana i Rossii: popytka sopostavitel'nogo analiza. [Migration Policy of Kazakhstan and Russia: Attempt of a Comparative Analysis.] Materialy X Mezhdunarodnoi nauchnoi konferentsii po problemam razvitiia ekonomiki i obshchestva. [Materials of the 10th International Scientific Conference on the Problems of Development of Economy and Society.] Moskva: Natsional'nyi issledovatel'skii universitet "Vysshaia shkola ekonomiki”. Available at http://www.hse.ru/news/recent/7523313.html, last accessed on January 26, 2016. 